\title{
The Purification, Physical/Chemical Characterization, and cDNA Sequence of Cantaloupe Fruit Polygalacturonase-Inhibiting Protein
}

\author{
Wayne W. Fish and Angela R. Davis
}

U.S. Department of Agriculture-Agriculture Research Service, SCARL, P.O. Box 159, Lane, OK 74555.

Accepted for publication 2 December 2003.

\begin{abstract}
Fish, W. W., and Davis, A. R. 2004. The purification, physical/chemical characterization, and cDNA sequence of cantaloupe fruit polygalacturonase-inhibiting protein. Phytopathology 94:337-344.

Polygalacturonase-inhibiting proteins (PGIPs) are believed to aid in plant defense against fungal pathogens by inhibiting polygalacturonases (PGs) secreted by the invading organism. In an effort to better understand this type of plant-pathogen interaction in cucurbits, we have isolated a cantaloupe PGIP (CmPGIP) from 5 to 15 day postanthesis cantaloupe fruit. CmPGIP inhibited crude extracts of PG from two of four fungal pathogens of cantaloupe that were tested. Results from assays for PG activity that utilized rate of substrate viscosity reduction or rate of reducing group formation were consistent with CmPGIP inhibition of endo-PG

activity. The $M_{\mathrm{r}}$ of CmPGIP by sedimentation equilibrium or MALDITOF MS was 38,500 . The $\mathrm{pI}$ of CmPGIP was $\approx 8.2$, and its absorptivity at $280 \mathrm{~nm}$ was $0.93 \mathrm{ml} / \mathrm{mg}$. The circular dichroism spectrum of native CmPGIP exhibited strong negative ellipticity in the near UV and possessed a far UV spectrum indicative of $\beta$-sheet periodic structure. Amino acid sequences of the $\mathrm{N}$ terminus and a cyanogen bromide peptide were used to construct oligonucleotide primers for polymerase chain reaction sequencing. The sequenced open reading frame predicts a mature protein of 307 amino acids with up to $68 \%$ identity to other PGIP molecules. Northern blot analysis revealed differential expression during fruit development. The isolation and structural information obtained for CmPGIP by this investigation provide a foundation for the development of molecular strategies for pre- and postharvest crop protection.
\end{abstract}

Plants are continually exposed to a broad spectrum of fungal pathogens, and one of the barriers that plants employ against the onslaught is their cell wall. The fungal pathogen breaches this multipolysaccharide barrier and gains access to the plant tissue by secreting a number of enzymes capable of partially degrading the structural cell wall polymers. Because pectin is a major component of plant cell walls, one of the classes of hydrolytic enzymes frequently put forth as important, if not critical, to fungal pathogenesis is endopolygalacturonases (PGs). They are among the first enzymes secreted when fungi are grown on plant cell walls in vitro $(24,30,37)$, and their action appears to facilitate other cell wall degradative enzymes reaching their respective substrates $(7,25)$. In the early 1970 s, glycoproteins were extracted from bean hypocotyl tissues, tomato stems, and sycamore cells that inhibited selected fungal PGs in vitro (3). Similar proteins from other plant families were subsequently isolated, and the designation, polygalacturonase inhibiting protein, or PGIP, was introduced.

The strength and specificity of the interaction between plant PGIPs and fungal PGs vary widely (reviewed in literature citation 13). PGIPs from a single plant tissue will differentially inhibit PGs from various fungi $(1,11,15)$ or iso-PGs from the same fungus (43). The complex that is formed between the enzyme and inhibitor in vitro results in an alteration in the balance of products

Corresponding author: W. W. Fish; E-mail address: wfish-usda@lane-ag.org

Mention of trade names or commercial products in this article is solely for the purpose of providing specific information and does not imply recommendation or endorsement by the U.S. Department of Agriculture (USDA). All programs and services of the USDA are offered on a nondiscriminatory basis without regard to race, color, national origin, religion, sex, age, marital status, or handicap.

Publication no. P-2004-0206-02R

This article is in the public domain and not copyrightable. It may be freely reprinted with customary crediting of the source. The American Phytopathological Society, 2004. derived from the action of PG on pectin (22). PG-PGIP complex formation favors a release of elicitor-active oligogalacturonides over the customary PG-catalyzed hydrolysis of pectin to di- and trigalacturonides. pgip genes have now been cloned from a wide array of plant species where they usually exist as gene families (13). Analyses of gene sequences have indicated that PGIPs possess the versatile structural motif of leucine-rich repeats (LRRs) $(12,39)$ found in many proteins and appear to be involved in protein-protein interactions (23).

Cucurbits, which are an important food source worldwide, are subject to a broad spectrum of fungal diseases. In light of their economic importance internationally, we found it curious that no information has been forthcoming about cucurbit-derived PGIPs. Literature is limited to two reports that substantiate their presence $(27,37)$. The purpose of this research was to isolate and characterize PGIP from a member of the cucurbit family as a prelude toward developing an understanding of its interactions with PGs from a selection of cucurbit fungal pathogens.

\section{MATERIALS AND METHODS}

Reagents. Oligonucleotide primers were synthesized by Gibco BRL Invitrogen Life Technologies (Gaithersburg, MD). Total RNA was isolated using TRIzol reagent (Gibco BRL Invitrogen Life Technologies). BrightStar Biotinylated RNA Millennium RNA Markers (Ambion, Austin, TX) were used for size standards on denaturing RNA gels, which were run using the NorthernMax Kit (Ambion). Visualization of pgip mRNA was performed using BrightStar Detection Kits (Ambion) and a Kodak Image Station 440CF (Eastman Kodak Co., Rochester, NY).

Source materials for PG. Fungal pathogens, Phomopsis $\mathrm{cu}$ curbitae, Fusarium solani, F. verticillioides (synonym $=F$. moniliforme; J. Sheld; teleomorph = Gibberella fujikuroi (Sawada) Ito in Ito \& K. Kimura, mating population A), and Didymella bryoniae were provided by B. Bruton, U.S. Department of Agriculture. Fungal PG was prepared from cantaloupe fruit by inocu- 
lating cantaloupe fruit according to published procedures (4446). Mature, full-slip fruit were inoculated with $F$. solani, F. verticillioides, or P. cucurbitae, whereas 10-day-old fruit were used to grow $D$. bryonae. Lesions were harvested 6 days after inoculation for all organisms except those of $F$. verticillioides that were 8 days old. An enzyme extract was prepared from lesions by grinding in an equal weight of $2 \mathrm{M} \mathrm{NaCl}$ in $0.05 \mathrm{M}$ sodium acetate buffer, $\mathrm{pH}$ 5.0. After centrifugation at $10,000 \times g$ at $15^{\circ} \mathrm{C}$ for $30 \mathrm{~min}$ to remove insoluble material, the extract was concentrated $\approx 20$ - to 50 -fold on an Amicon YM-10 membrane (Millipore Corp., Bedford, MA) and transferred to $0.05 \mathrm{M}$ sodium acetate buffer, pH 5.0, by diafiltration with the Amicon YM-10 membrane. Commercial preparations of $\mathrm{PG}$ from Aspergillus niger and Rhizopus sp. (Sigma Chemical, St. Louis) were used without further purification.

Purification of cantaloupe PGIP. 'Copa de Oro' cantaloupe (Cucumis melo var. reticulatas) from the 2000 crop at Lane Ag Center (Lane, OK) were harvested at 5 to 10 days postanthesis. Fruit were diced, and $3.6 \mathrm{~kg}$ of tissue was added to $400 \mathrm{ml}$ of deionized water and blended for 5 min (Waring Products, New Hartford, CT). The ground material was frozen in zip-lock plastic bags at $-15^{\circ} \mathrm{C}$ until processing. The ground cantaloupe tissue was thawed and preextracted in batches of $1.8 \mathrm{~kg}$ (1.6 kg of tissue). The preextraction process consisted of washing the tissue solids five times with 2 liters of water, once with 2 liters of $0.1 \mathrm{M} \mathrm{NaCl}$

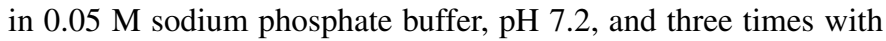
$0.05 \mathrm{M}$ sodium phosphate buffer, $\mathrm{pH}$ 7.2. Solubilization of PGIP from the prewashed cantaloupe tissue was accomplished by extraction with 2 liters of $0.6 \mathrm{M} \mathrm{NaCl}$ in $0.05 \mathrm{M}$ sodium phosphate buffer, $\mathrm{pH} 7.2$, by stirring at $7^{\circ} \mathrm{C}$ for $2 \mathrm{~h}$. This was followed by separation of liquid and solids by filtration through parachute cloth and centrifugation at $10,000 \times g$ for $30 \mathrm{~min}$ at $15^{\circ} \mathrm{C}$. The material that solubilized in the $0.6 \mathrm{M} \mathrm{NaCl}$ was concentrated from 2 liters to $\approx 150 \mathrm{ml}$ on a Minitan membrane concentrator (Millipore) with a Minitan Biomax PB plate of 10,000 MW cutoff. The extract $(\approx 150 \mathrm{ml})$ was further concentrated to $\approx 15 \mathrm{ml}$ with a YM-10 membrane (Millipore) in an Amicon concentrator. The crude, concentrated cantaloupe PGIP (CmPGIP) extract was diafiltered into $0.05 \mathrm{M}$ sodium phosphate buffer, $\mathrm{pH} 7.2$, while in the Amicon concentrator.

The CmPGIP extract was subjected to cation exchange chromatography on a strong cation exchanger (Bio-Rad MP25S; BioRad Laboratories, Hercules, CA) packed in a bed (12 by $85 \mathrm{~mm}$ ) in a column (Bio-Rad MT10). Gradient elution and effluent monitoring at $280 \mathrm{~nm}$ were performed with an advanced protein purification system (Waters 650E; Waters Corp., Milford, MA) and a tunable absorbance detector (Waters 484). The column was operated at a flow rate of $1.5 \mathrm{ml} / \mathrm{min}$. The elution program after injection of the sample in $0.05 \mathrm{M}$ sodium phosphate buffer, $\mathrm{pH}$ 7.2, was as follows: (i) $10 \mathrm{~min}$ isocratic elution with $0.05 \mathrm{M}$ sodium phosphate buffer, $\mathrm{pH} 7.2$, (ii) a linear gradient from buffer only to buffer plus $0.5 \mathrm{M} \mathrm{NaCl}$ over $60 \mathrm{~min}$, (iii) a linear gradient from $0.5 \mathrm{M} \mathrm{NaCl}$ to $1 \mathrm{M} \mathrm{NaCl}$ in buffer over $10 \mathrm{~min}$, (iv) isocratic elution at $1 \mathrm{M} \mathrm{NaCl}$ in buffer for $10 \mathrm{~min}$, and (v) a $5 \mathrm{~min}$ linear gradient return to buffer only followed by $15 \mathrm{~min}$ of column reequilibration in buffer.

Gel filtration was performed on a bed $(1.6$ by $92.5 \mathrm{~cm})$ of BioGel P-100 (Bio-Rad) in a Pharmacia column (Amersham Pharmacia Biotek, Piscataway, NJ). The gel filtration medium was equilibrated in $0.2 \mathrm{M}$ sodium acetate buffer, $\mathrm{pH}$ 5.0. The flow rate, as maintained by a Pharmacia peristaltic pump, was $4 \mathrm{ml} / \mathrm{h}$ ( $2 \mathrm{~cm} / \mathrm{h}$ linear flow rate). One-milliliter samples were placed on the P-100 column and eluted at the above flow rate. Fractions $(\approx 2 \mathrm{ml})$ with constant specific activity for PGIP were pooled and concentrated in a Centriprep YM-10 (Millipore) tube to $5 \mathrm{ml}$.

PG and CmPGIP activity assays. PG activity was routinely assayed by measuring reducing groups released from sodium polygalacturonate by the method of Gross (20). D-Galacturonic acid was used as the standard to convert absorbance change to molar concentration of reducing groups formed. Assays were conducted at $30 \pm 1{ }^{\circ} \mathrm{C}$ in $0.05 \mathrm{M}$ sodium acetate, $\mathrm{pH}$ 5.0, at a substrate concentration of $0.1 \%$ (wt/vol) polygalacturonate. Apparent initial rates were estimated by a discontinuous assay where duplicate samples were removed from the incubation mixture at 0 , $2.5,5$, and $7.5 \mathrm{~min}$. The square of the correlation coefficient, $R^{2}$, for a linear least-squares fit to the eight points in an assay routinely ran $0.99 \pm 0.01$. Inhibition of PG activity by CmPGIP was estimated by conducting the assay for PG in the absence and presence of CmPGIP. Five to seven nanokatals (1 nmol of reducing groups formed per second) of PG activity were employed in each assay. PG and CmPGIP were preincubated at room temperature for $15 \mathrm{~min}$ followed by incubation at $30^{\circ} \mathrm{C}$ for $5 \mathrm{~min}$ before assaying residual PG activity. Following precedence established in earlier studies $(3,8,40,43)$, one unit of PGIP was defined as the amount of inhibitor required to reduce one unit of PG activity by $50 \%$.

In some instances, endo-PG activity was estimated by measuring the decrease in reduced viscosity of $1.0 \mathrm{ml}$ of enzyme or enzyme plus inhibitor in a $0.1 \%$ (wt/vol) solution of sodium poly-

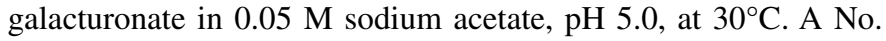
75 Cannon-Manning Semi-micro Viscometer (water flow time of $\approx 130 \mathrm{~s}$; Cannon Instrument Co., State College, PA) was utilized. Temperature was controlled at $30.07 \pm 0.02^{\circ} \mathrm{C}$ in a viscometer bath (Cannon CT-500; Cannon Instrument). Employment of $\approx 5$ nkat of endo-PG in the viscometric system resulted in a linear rate of decrease in reduced viscosity $\left(R^{2}=0.98 \pm 0.1\right)$ over the first $15 \mathrm{~min}$ of the reaction.

Physical measurements. Sodium dodecyl sulfate-polyacrylamide gel electrophoresis (SDS-PAGE) was performed in a BioRad Mini-Protean III apparatus according to the procedure of Laemmli (26). Gels were stained for protein with Coomassie blue and for carbohydrate by the periodic acid-Schiff stain (19) with commercially prepared reagents (Pierce, Rockford, IL). Isoelectric focusing was performed on $18 \mathrm{~cm}$ Immobiline Dry Strips, $\mathrm{pH}$ 6 to 11 , at $20^{\circ} \mathrm{C}$ with a Multiphor II IEF/Electrophoresis system according to the manufacturer's instructions (Amersham Pharmacia Biotech) or in vertical slab gels ( 8.3 by $7.3 \mathrm{~cm}$ by $0.75 \mathrm{~mm}$ ) (4). Gel chromatography in $6 \mathrm{M}$ guanidinium chloride $(\mathrm{gdmCl})$ followed published procedures (31). Cross-linked 6\% agarose (Amersham Pharmacia Biotech) equilibrated in $6 \mathrm{M} \mathrm{gdmCl}$ (Sigma, grade I) was employed in a Pharmacia column $(1.6$ by $100 \mathrm{~cm})$. A flow rate of $1.4 \mathrm{~g} / \mathrm{h} / \mathrm{cm}^{2}$ was used and $\approx 1$-g fractions were collected. Data were treated in the common fashion for estimating molecular weight and Stokes radius, $R_{\mathrm{s}}(16)$.

The absorptivity at $280 \mathrm{~nm}$ of CmPGIP was experimentally estimated by the procedure of Scopes (36). Absorbance readings were taken on a Perkin-Elmer Lambda 3B spectrophotometer (Perkin-Elmer Corp., Wellesley, MA) in $1 \mathrm{~cm}$ quartz cuvettes. The absorptivity was also predicted from the inferred amino acid composition by the equation of Pace et al. (34). Circular dichroism spectra were measured in the laboratory of J. Soulages, Oklahoma State University, with a Jasco J-715 instrument (Jasco Ltd., Japan). For spectra in the near UV, a CmPGIP concentration of $2.2 \mathrm{mg} / \mathrm{ml}\left(A_{280}=2.05\right)$ in $0.1 \mathrm{M} \mathrm{NaCl}$ plus $0.05 \mathrm{M}$ sodium acetate buffer, $\mathrm{pH} 5.0$, was used in a $1 \mathrm{~cm}$ path length quartz cell. In the far UV, a cell path length of $0.1 \mathrm{~cm}$ was utilized. Protein concentrations of 0.22 and $0.044 \mathrm{mg} / \mathrm{ml}$ in $5 \mathrm{mM}$ sodium acetate buffer plus $10 \mathrm{mM} \mathrm{NaCl}, \mathrm{pH}$ 5.0, were employed for this wavelength region. The SELCON curve-fitting algorithm of Sreerama and Woody (38) was used to estimate the percentages of secondary structural elements.

Equilibrium analytical ultracentrifugation was performed on a Beckman XL-A instrument (absorption optics only) with an An$60 \mathrm{Ti}$ rotor and a six channel epon-charcoal centerpiece held at $20^{\circ} \mathrm{C}$ (Beckman Coulter, Fullerton, CA). Equilibrium runs were performed at 17,000 and 25,000 rpm. 
Mass spectrometry of CmPGIP was carried out by the Recombinant DNA/Protein Resource Facility at Oklahoma State University (Stillwater) on an Applied Biosystems PE-PRO MALDITOF mass spectrometry workstation (Applied Biosystems, Foster City, CA). Sinapinic acid was employed as the matrix. The instrument was operated in the linear mode. Spectra represented 20 spectra at 50 shots per spectrum. Mass of the intact CmPGIP was determined by internal calibration by employing bovine serum albumin $(\mathrm{BSA})+1\left(M_{\mathrm{r}}=66,431\right)$ and BSA+2 $\left(M_{\mathrm{r}}=33,216\right)$ ions. Mass of the isolated CNBr-generated peptide was determined by internal calibration by employing thioredoxin $+1\left(M_{\mathrm{r}}=11,675\right)$ and apomyoglobin $+1\left(M_{\mathrm{r}}=16,953\right)$. Spectra were subjected to 17 point Gaussian smoothing and de-isotoping.

Chemical properties. Protein and peptide sequencing was performed on a Procise 491 automated protein sequencer (Applied Biosystems) by the Oklahoma State University Recombinant DNA/Protein Resource Facility. Sequencing was repeated at least three times on each sample. Before sequencing, CmPGIP protein or peptides were reduced with 1,4-dithio-DL-threitol and alkylated with 4-vinylpyridine in $6 \mathrm{M} \mathrm{gdmCl}$ in $1 \mathrm{M}$ Tris- $\mathrm{HCl}$, $\mathrm{pH} 8.4$.

CNBr cleavage was performed on $4.5 \mathrm{mg}$ of CmPGIP in $0.3 \mathrm{ml}$ of $70 \%$ formic acid with a ratio of $\approx 200 \mathrm{~mol} \mathrm{CNBr}$ per mole CmPGIP (ultimately $50 \mathrm{~mol} \mathrm{CNBr} /$ mole Met). The reaction proceeded in the dark at room temperature for $24 \mathrm{~h}$. Reagents were removed by adding 10 volumes of deionized $\mathrm{H}_{2} \mathrm{O}$ and lyophilizing the reaction mixture. The residue was dissolved in $6 \mathrm{M} \mathrm{gdmCl}$ and subjected to gel filtration on a calibrated column (1.6 by $95 \mathrm{~cm}$ ) of Superdex 200 (Amersham Pharmacia Biotech) equilibrated in $6 \mathrm{M}$ gdmCl. Individual peaks were pooled, desalted, and analyzed by SDS-PAGE before selection of fragments for sequencing.

Determination of CmPGIP sulfhydryl content was performed in $1 \%$ SDS in $0.1 \mathrm{M}$ sodium phosphate buffer, $\mathrm{pH} 8.0$, by the procedure outlined by Habeeb (21).

PCR sequencing. RNA was extracted from a 'Magnum 45' cantaloupe 5 days postanthesis. Total RNA was extracted using the TRIzol reagent (Gibco BRL Invitrogen Life Technologies). The RNA was reverse transcribed using the SOLIDscript Solid Phase cDNA Synthesis Kit (CPG Inc., Lincoln Park, NJ). The 5' end of the cantaloupe pgip gene was polymerase chain reaction (PCR) amplified by producing degenerate primers (synthesized by Gibco BRL Invitrogen Life Technologies) from the N-terminal and central peptide sequences determined from purified CmPGIP protein (described below in chemical properties). The product was then sequenced and internal primers were designed for use in $5^{\prime}$ and $3^{\prime}$ rapid amplification of cDNA ends (RACE; Gibco BRL Invitrogen Life Technologies). This procedure was performed to obtain the remainder of the $5^{\prime}$ and $3^{\prime}$ sequences.

All PCR reactions, excluding $5^{\prime}$ RACE, were performed following standard protocols (5) and Ready-To-Go PCR Beads
(Amersham Pharmacia Biotech) and a MiniCycler Instrument (MJ Research, Waltham, MA). PCR sequencing was carried out by the Oklahoma State University Recombinant DNA Resource Facility. PCR samples were amplified and sequenced in the forward and reverse directions from at least two PCR reactions to check for any possible mutations introduced by the polymerase.

Northern analysis. Total RNA was isolated from the seed cavity of mature (35 days postanthesis) and immature ( 2 days postanthesis) 'Magnum 45' cantaloupe. Seeds were removed from the mature fruit but remained in the RNA sample of the immature fruit. One milliliter of TRIzol per $100 \mathrm{mg}$ of sample was used following the company protocol. Both optional steps to reduce polysaccharide contamination were performed. Total RNA $(15 \mu \mathrm{g})$ from mature and immature cantaloupe fruit was run on a denaturing RNA gel and transferred to BrightStar-Plus positively charged nylon membrane (Ambion) with the NorthernMax kit (Ambion) according to the company's protocol. Visualization of the pgip message was performed with the BrightStar Psoralen-Biotin Nonisotopic Labeling Kit to label a full-length cantaloupe pgip sequence. The probe was amplified by PCR and sequenced for verification of the amplified product. Blots were washed under high stringency conditions and visualized using a Kodak Image Station 440CF (Eastman Kodak).

\section{RESULTS}

Extraction and purification of CmPGIP. Preliminary tests on young cantaloupe plants and cantaloupe fruit at various stages of maturity indicated that fruit at $<10$ day postanthesis were the richest source of CmPGIP activity (data not shown). As shown in the purification scheme summarized in Table 1, the batch preextraction of the tissue before solubilization of the CmPGIP afforded an almost 60 -fold purification step with less than a $20 \%$ loss of PGIP activity. Seven protein peaks were obtained upon cation exchange chromatography of the CmPGIP extract, and one peak exhibited the vast majority of the PGIP activity, $\approx 98 \%$, versus $P$. cucurbitae PG. This CmPGIP activity eluted in a somewhat broad, symmetrical peak at about $0.22 \mathrm{M} \mathrm{NaCl}$. When the fractions from the peak of PGIP activity were pooled, concentrated, reequilibrated in starting buffer, and reapplied to the column, PGIP activity and protein eluted in a symmetrical peak at the same $\mathrm{NaCl}$ concentration. Rechromatography of the PGIPcontaining fractions with a shallower gradient affected no additional resolution.

Gel filtration of the pooled CmPGIP fractions from ion exchange yielded a single symmetrical peak with little increase in specific activity of the preparation. At this point, the CmPGIP activity had been purified over 540 -fold at a yield of $28 \%$. SDSPAGE of the preparation followed by staining for protein and for carbohydrate indicated that the electrophoretic component, pre-

TABLE 1. Purification of cantaloupe polygalacturonase-inhibiting proteins (CmPGIP) from immature cantaloupe fruit

\begin{tabular}{|c|c|c|c|c|c|c|c|}
\hline Purification step & $\begin{array}{l}\text { Volume } \\
\qquad(\mathrm{ml})\end{array}$ & $\begin{array}{l}\text { PGIP } \\
\text { (units/ml)a }\end{array}$ & $\begin{array}{l}\text { Total PGIP } \\
\quad \text { (units) }\end{array}$ & $\begin{array}{l}\text { Protein } \\
(\mu \mathrm{g} / \mathrm{ml})\end{array}$ & $\begin{array}{l}\text { Total protein } \\
(\mathrm{mg})\end{array}$ & $\begin{array}{l}\text { Species activity } \\
\text { (units/mg of protein) }\end{array}$ & $\begin{array}{l}\text { Yield } \\
(\%)\end{array}$ \\
\hline $\begin{array}{l}\text { Extraction of } 1.6 \mathrm{~kg} \text { of fruit tissue with } 2 \text { liters of } 0.05 \mathrm{M} \\
\mathrm{PO}_{4} \text { plus } 0.6 \mathrm{M} \mathrm{NaCl}, \mathrm{pH} 7.2 \\
\text { Extraction of residue from } 1.6 \mathrm{~kg} \text { of fruit tissue with }\end{array}$ & 3,185 & 11.7 & 37,100 & 2,470 & 7,867 & 4.72 & 100 \\
\hline $\begin{array}{l}\text { Extraction of residue from } 1.6 \mathrm{~kg} \text { of fruit tissue with } \\
2 \text { liters of } 0.05 \mathrm{M} \mathrm{PO}_{4} \text { plus } 0.6 \mathrm{M} \mathrm{NaCl}, \mathrm{pH} 7.2 \text {, after } \\
\text { exhaustive preextraction }\end{array}$ & 2,000 & 15.4 & 30,900 & 0.056 & 112 & 276 & 83 \\
\hline $\begin{array}{l}\text { Concentration of extract with Minitan and then Amicon } \\
\text { membrane concentrators }\end{array}$ & 14.9 & 1,540 & 23,000 & 4,295 & 64 & 359 & 62 \\
\hline $\begin{array}{l}\text { Anion exchange chromatography on Bio-Rad MP25, peak } \\
\text { eluting at } 0.22 \mathrm{M} \mathrm{NaCl} \text { in } 0.05 \mathrm{M} \mathrm{PO}_{4}, \mathrm{pH} 7.2\end{array}$ & 34 & 331 & 11,300 & 133 & 4.5 & 2,510 & 30 \\
\hline $\begin{array}{l}\text { Gel filtration on } \mathrm{P}-100 \text { in } 0.2 \mathrm{M} \text { acetate, } \mathrm{pH} 5.0 \text {, and then } \\
\text { concentration }\end{array}$ & 5.0 & 2,070 & 10,400 & 800 & 4.0 & 2,590 & 28 \\
\hline
\end{tabular}

a Solutions were exchanged into $0.05 \mathrm{M}$ sodium acetate buffer, $\mathrm{pH}$ 5.0, before assaying for PGIP activity.

${ }^{b}$ Preextraction process: tissue preextracted five times, each time for 30 min with 2.1 liters of deionized $\mathrm{H}_{2} \mathrm{O}$ at $7^{\circ} \mathrm{C}$; once for $16 \mathrm{~h}$ with 2 liters of $0.05 \mathrm{M}$ sodium phosphate buffer plus $0.1 \mathrm{M} \mathrm{NaCl}, \mathrm{pH} 7.2$, at $7^{\circ} \mathrm{C}$; and finally three times, each time for 30 min with 2 liters of $0.05 \mathrm{M}$ sodium phosphate buffer, $\mathrm{pH} 7.2$, at $7^{\circ} \mathrm{C}$. 
sumably CmPGIP, was a glycoprotein (17). SDS-PAGE and Coomassie staining of successive dilutions of the preparation suggested that the CmPGIP was $>90 \%$ pure (data not shown). Assays for other biological activities indicated the presence of trace levels of pectin methylesterase activity in the purified CmPGIP preparations, but no protease or pectin lyase activities were detected.

We found that CmPGIP was stable both in $0.05 \mathrm{M}$ sodium phosphate buffer, $\mathrm{pH} 7.2$, and in $0.05 \mathrm{M}$ sodium acetate buffer, $\mathrm{pH} 5.0$, from 4 to $10^{\circ} \mathrm{C}$. However, upon freezing the protein, much of the inhibitor's activity was lost in the $0.05 \mathrm{M}$ sodium phosphate. This inactivation/denaturation in the presence of sodium phosphate may be the result of significant $\mathrm{pH}$ changes during freezing and thawing (35). CmPGIP could be stored frozen at $-20^{\circ} \mathrm{C}$ in $0.05 \mathrm{M}$ sodium acetate buffer, $\mathrm{pH} 5.0$, for up to a year without detectable loss in activity.

Functional properties. Figure 1 summarizes the interaction of CmPGIP with extracts of PG from six fungi, four of them known fungal pathogens of cantaloupe fruit, i.e., P. cucurbitae, F. solani, $F$. verticillioides, and $D$. bryoniae. CmPGIP inhibited PG activity from $F$. solani, $P$. cucurbitae, and A. niger, whereas little or no measurable inhibition could be achieved for $F$. verticillioides, $D$. bryoniae, and Rhizopus PG(s). P. cucurbitae PG purified by binding to agarose-CmPGIP (data not shown) was inhibited to $90 \%$ by CmPGIP in solution, although we were unable to achieve complete inhibition. The rate of decrease of reduced specific viscosity of $0.1 \%$ polygalacturonate in the presence of enzyme or enzyme plus inhibitor was also determined for each of the PGs from three

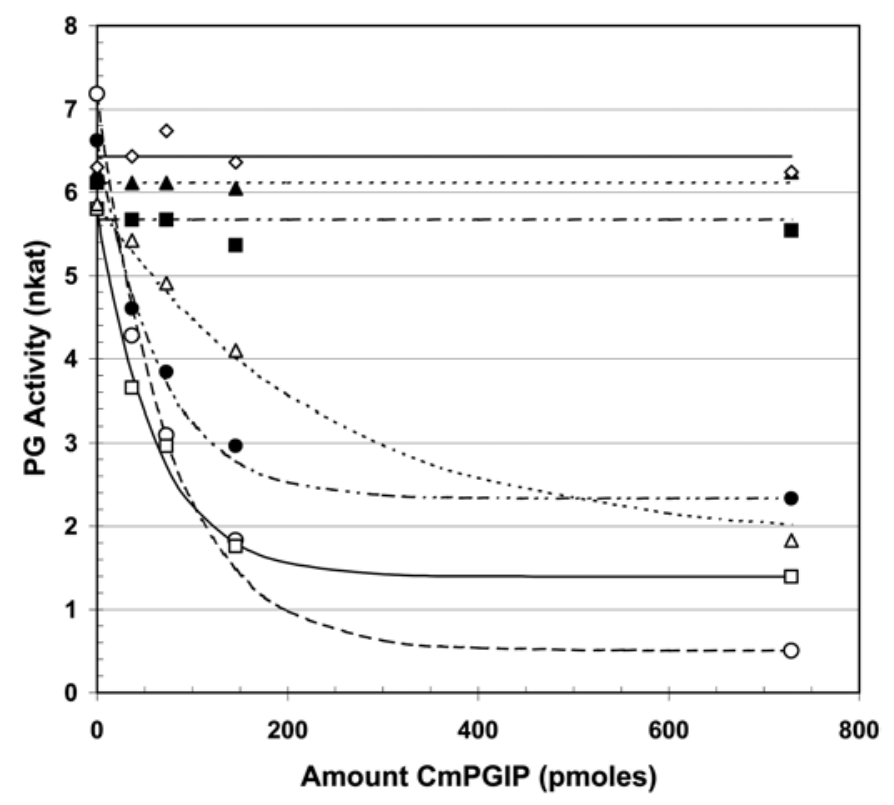

Fig. 1. Interaction of cantaloupe polygalacturonase-inhibiting proteins (CmPGIP) with PGs from selected fungi. Various levels of pure CmPGIP were incubated with crude extracts of fungal lesions or commercial PG preparations, all at constant levels of PG activity. Open circles, Phomopsis cucurbitae PG purified on a CmPGIP affinity column; open squares, Fusarium solani lesion extract; open triangles, commercial Aspergillus niger preparation; open diamonds, F. verticillioides lesion extract; closed circles, P. cucurbitae lesion extract; closed squares, Didymella bryoniae lesion extract; and closed triangles, commercial Rhizopus sp. preparation. The experimental points for $P$. cucurbitae purified PG, P. cucurbitae lesion extract, $F$. solani lesion extract, and $A$. niger $\mathrm{PG}$ were individually fit with curves of the following form: $P_{w}=\left(P_{\text {init }}-P_{\min }\right) \times[\exp (-k \times w)]+P_{\min }$, where $P_{w}$ is the observed PG activity at $w$ pmoles of PGIP, $P_{\text {init }}$ is the observed PG activity in the absence of PGIP, $P_{\min }$ is the residual reducing activity at maximal PGIP inhibition, $w$ is the pmoles of PGIP added, and $k$ is an empirically derived constant to give the best fit of the curve to the data. No physical significance is implied for the constant $k$. The experimental points for D. bryoniae, F. verticillioides, and Rhizopus sp. PGs are fit with straight lines of slope $=0$. of the cantaloupe pathogens. Inhibitor was used at a level sufficient to achieve maximal inhibition of the enzyme in the reducing group-forming spectrophotometric assay. CmPGIP slowed the rate of viscosity reduction of substrate by $99 \%$ with $F$. solani extract, $93 \%$ with $P$. cucurbitae extract, and $0 \%$ with $D$. bryoniae extract. These data are consistent with CmPGIP being able to inhibit most or all of the endo-PG activity from $P$. cucurbitae and $F$. solani, but being totally ineffective against endo-PG from $D$. bryoniae. Heat denatured CmPGIP exhibited no inhibitory effect on the endo-PG activity of any of the three extracts.

Physical properties. Table 2 summarizes the physical properties determined for CmPGIP. The native molecular weight as estimated by sedimentation equilibrium or gel chromatography was the same as that measured under denaturing conditions by SDSPAGE, gel chromatography in $6 \mathrm{M} \mathrm{gdmCl}$, or MALDI-TOF MS. Together, these results indicate that CmPGIP is a monomeric protein in the native state. The $R_{\mathrm{e}} / R_{\min }=1.28$ by gel chromatography in dilute buffer is consistent with CmPGIP being a globular protein. We observed that the Stokes radius, $R_{\mathrm{s}}$, of the disulfide crosslinked randomly coiled form of CmPGIP, $5.45 \mathrm{~nm}$, is only $20 \%$ less than that of the randomly coiled linear form (i.e., disulfide bonds reduced), $5.87 \mathrm{~nm}$. Such behavior would suggest that there is limited or very localized restraint imposed on the polypeptide chain by intrachain disulfide bonds.

Efforts to experimentally estimate the pI of CmPGIP on commercial gels and on gels that we prepared were not successful. Thus, we can only report that the pI predicted from the amino acid sequence of mature CmPGIP is 8.2. The absorptivity of CmPGIP used for concentration determinations, $0.93 \mathrm{ml} / \mathrm{mg}$, was determined by the method of Pace et al. (34) from the inferred amino acid sequence of CmPGIP. The experimentally estimated value (36), $0.72 \mathrm{ml} / \mathrm{mg}$, was deemed less reliable because of its susceptibility to error-inducing factors such as stray light or errors in the wavelength setting.

Figure 2 presents the near- and far UV circular dichroic spectra of CmPGIP. Overall, the far UV circular dichroism (CD) spectrum suggests that any periodic secondary structure of the protein is dominated by $\beta$-sheet. Prediction of the proportions of secondary structures from the spectrum suggests around $30 \% \beta$-sheet structure and as much as $23 \%$ turns. This is in reasonable agreement with values recently reported for Phaseolus vulgaris (bean) PGIP (44) of $34.6 \% \beta$-strand and $21.5 \%$ turns. The inset of Figure 2 shows the near UV CD spectrum. It would appear that the signal is dominated by Tyr $(2,6)$ residues and disulfide bond(s) (6) with a Trp signal visible at $\approx 295 \mathrm{~nm}(2)$.

TABLE 2. Physical properties of cantaloupe polygalacturonase-inhibiting proteins (CmPGIP) from cantaloupe fruit

\begin{tabular}{lc}
\hline Property & Value \\
\hline Native molecular weight by sedimentation equilibrium & \\
$\quad$ in dilute buffer $(v=0.734)$ & $37,500 \pm 700$ \\
$R_{\mathrm{s}}$ by gel chromatography in dilute buffer & $2.86 \mathrm{~nm}$ \\
$R_{\mathrm{s}} / R_{\text {min }}$ by gel chromatography & 1.28 \\
Molecular weight by SDS-PAGE & $39,400 \pm 2,000$ \\
Molecular weight by gel chromatography in 6 M gdmCl & $38,000 \pm 2,000$ \\
Molecular weight by MALDI-TOF MS & 38,431 \\
Molecular weight of mature polypeptide chain inferred & \\
by cDNA sequence & 34,346 \\
Apparent percentage of attached oligosaccharides & $10.6 \%$ \\
$R_{\mathrm{s}}$ of random coil in $6 \mathrm{M}$ gdmCl & $5.87 \pm 0.15 \mathrm{~nm}$ \\
$R_{\mathrm{s}}$ of S-S cross-linked random coil in $6 \mathrm{M}$ gdmCl & $5.45 \pm 0.15 \mathrm{~nm}$ \\
pI (estimated) & 8.2 \\
Absorptivity at 280 nm & $0.93 \mathrm{ml} / \mathrm{mg}$ \\
Secondary structure estimated by CD & \\
$\alpha-H e l i x$ & $11 \pm 2 \%$ \\
$\beta$-Sheet, antiparallel & $25 \pm 5 \%$ \\
$\beta$-Sheet, parallel & $7 \pm 2 \%$ \\
Turn & $23 \pm 3 \%$ \\
Other & $38 \pm 5 \%$ \\
\hline
\end{tabular}


Chemical properties. N-terminal sequencing of CmPGIP yielded the following sequence: Glu-Leu-Cys-His-Pro-Asn-AspLys-Glu-Val-Leu-Leu-Asn-Ile-Lys-Ala-Phe-Asn-Asn-Pro-Tyr-Ile. CmPGIP was cleaved at Met residues by treatment with $\mathrm{CNBr}$. Cleavage products were then separated by size by gel chromatography in $6 \mathrm{M} \mathrm{gdmCl}$. Four peaks were obtained with the following Stokes radii: 6.1, 4.7, 3.5, and $2.7 \mathrm{~nm}$. These fractions were further evaluated by SDS-PAGE. Material from the first three peaks exhibited multiple bands. Only a single band of $M_{\mathrm{r}}=$ 12,600 by SDS-PAGE was observed for the $2.7 \mathrm{~nm}$ peak while its estimated $M_{\mathrm{r}}$ by gel chromatography in $6 \mathrm{M}$ gdmCl was $\approx 9,500$. This differential behavior between the two methods suggested that oligosaccharide was covalently attached to the polypeptide chain. This CNBr peptide was analyzed by MALDI-TOF MS. Its mass spectrum gave rise to a predominant peak of $9,881 \mathrm{~m} / \mathrm{z}$ and smaller peaks at $8,883,9,746$, and $10,043 \mathrm{~m} / \mathrm{z}$. The mass difference between the major species and the species at 10,043 is 162 and is suggestive of a hexose residue difference, whereas the difference between the major species and that at 9,746 is suggestive of a pentose residue difference (33). Each of the aforementioned mass species also had a shadowing peak of 28 mass units greater mass. We suspect these to be formulation derivatives of their parent species. The $2.7 \mathrm{~nm} \mathrm{CNBr}$ peptide was subjected to $\mathrm{N}$-terminal sequencing and the following sequence was obtained: Gly-Lys-Val-Asp-Phe-Asn-Tyr-Ile-Asp-Leu-Ser-Arg-Asn-LysLeu-Val-Gly-Asp-Gly-Ser-Leu-Ile. This sequence aligns with a PGIP region starting at residue 195 of bean PGIP. The exact position number differs among PGIPs from different sources. These two amino acid sequences from two widely separated regions of the protein were subsequently used to design oligonucleotides for amplification of pgip for sequencing.

pgip sequence. Using the PCR techniques mentioned previously, we sequenced 992 nucleotides of Cmpgip cDNA that contained a complete open reading frame of 978 nucleotides and encoded 326 amino acids. The complete nucleotide and amino acid sequences for Cmpgip can be viewed at GenBank (accession no. AY288911). A comparative alignment is shown in Figure 3. The predicted molecular weight of the full-length protein is 36,612 and 34,346 for the mature protein. The leader sequence for CmPGIP is Met-His-Ser-His-Asn-Leu-Leu-Leu-Leu-Leu-Phe-PhePhe-Phe-Thr-Val-Ser-Phe-Ala and is cleaved off to make the mature protein. This leader sequence is similar to the leader sequences from some of the other cloned PGIPs (9). A BLAST search with the mature CmPGIP revealed high similarity to other PGIP homologues, with apple (Malus domestica) (42) having the highest identity $(68 \%$ over the entire length of the mature protein).

pgip message. As illustrated in Figure 4, northern blot analysis of total RNA isolated from mature (35 days postanthesis) and immature ( 2 days postanthesis) cantaloupe fruit tissue revealed a band of $1.25 \mathrm{~kb}$ in immature fruit and no detectable band in mature fruit. The $1.25-\mathrm{kb}$ message is consistent with a 978 -bp predicted open reading frame plus $5^{\prime}$ and $3^{\prime}$ untranslated regions.

\section{DISCUSSION}

To our knowledge, this is the first report of the isolation and characterization of a cucurbit PGIP. CmPGIP is obtained through a 550-fold purification from immature cantaloupe fruit. Our molecular weight measurements under native and denaturing conditions unequivocally demonstrate that CmPGIP is a monomeric, globular protein in its native state. The far UV CD spectrum of CmPGIP is qualitatively and quantitatively similar to that for bean PGIP (32) and suggests $\beta$-sheet is the predominant type of periodic secondary structure. Secondary structural predictions for the CmPGIP polypeptide chain from its amino acid sequence by two different algorithms $(10,18)$ did not yield a clear consensus of locations of each type of periodic structure. Both methods did predict, however, a markedly higher proportion of $\beta$-sheet/ $\beta$-turn structures than of $\alpha$-helix, and this is consistent with the far UV $\mathrm{CD}$ spectrum. This is the first published spectrum of the near-UV CD of a PGIP. The moderately strong signals for Tyr and Trp in this region suggest that it may offer a possible spectral target for study of the microenvironmental changes of selected aromatic side chains in PGIP as a result of the interaction between PG and PGIP.

The hydrodynamic behavior of S-S cross-linked randomly coiled CmPGIP compared with that of its randomly coiled linear form is consistent with the disulfide bonds in the chain occurring between cysteines relatively close to one another in the linear sequence (41). Our observation is consistent with the location of disulfide bonds in Phaseolus vulgaris PGIP determined by mass spectra/proteolytic digestion (32). Although the inferred sequence of CmPGIP requires that the protein possess one free sulfhydryl (Cys 38), chemical modification suggested only $\approx 0.2$ sulfhydryls per molecule. Either not all of the population of sulflydryls was available for modification in SDS or the gene sequence that we determined is for a different PGIP that has a Cys in that position whereas the protein we isolated does not. As with nearly all PGIPs, eight of the nine Cys are conserved in the sequence (Fig. 3) which further suggests that the CmPGIP is disulfide constrained in a manner identical to bean PGIP. This appears not to be the case for all PGIPs, however. In eucalyptus, the mature polypeptide chain begins after Cys 3, and Cys 306 is substituted (9). In Citrus sinesis, Fortunella margarita, and Poncirus trifolata (alignments provided in literature citation 13), the polypeptide chain terminates before Cys 306. This means that one or two of the S-S bonds are likely absent in these inhibitors, and according to their inferred amino acid sequences, they each should possess

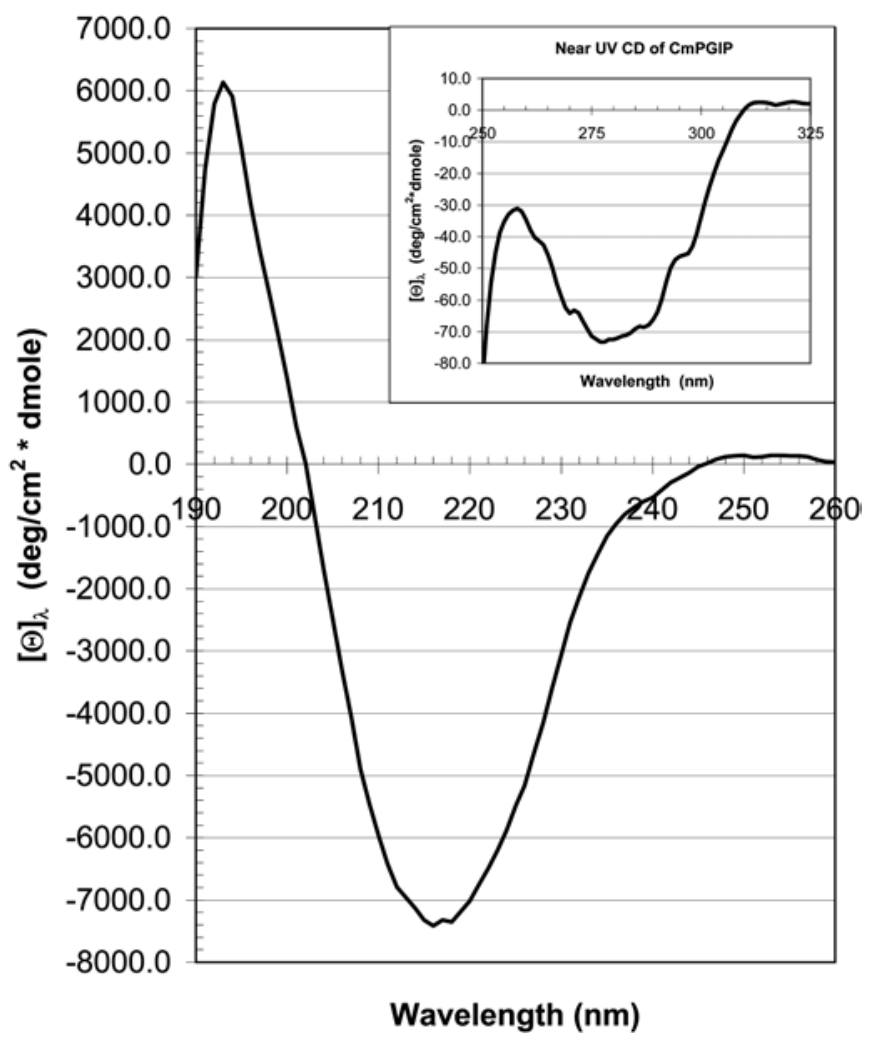

Fig. 2. Circular dichroism spectrum of cantaloupe polygalacturonaseinhibiting proteins (CmPGIP). The far UV CD spectrum was measured at $25^{\circ} \mathrm{C}$ with protein concentrations of 0.22 and $0.044 \mathrm{mg} / \mathrm{ml}$ in $5 \mathrm{mM}$ sodium acetate buffer plus $10 \mathrm{mM} \mathrm{NaCl}, \mathrm{pH} 5.0$, in a $0.1 \mathrm{~cm}$ path length quartz cell. Inset: The near UV CD spectrum of CmPGIP at $25^{\circ} \mathrm{C}$ in a $1 \mathrm{~cm}$ path length quartz cell at a protein concentration of $2.2 \mathrm{mg} / \mathrm{ml}$ in $0.1 \mathrm{M} \mathrm{NaCl}$ plus $0.05 \mathrm{M}$ sodium acetate buffer, $\mathrm{pH} 5.0$. 
two free sulfhydryls. The sequence fidelity for the $10.5 \mathrm{LRRs}$ postulated for PGIP $(12,39)$ is maintained in CmPGIP. Positions containing met are not conserved among the various PGIPs. Only one of four mets in mature CmPGIP is in a homologous position with those of its closest PGIP homologs.

Three potential N-glycosylation sites are predicted from the sequence of CmPGIP. They are at Asn 83, Asn 231, and Asn 268. Asn 231 resides within the peptide that we isolated from $\mathrm{CNBr}$ cleavage of CmPGIP. Mass spectral measurements suggest the nominal mass of that (glyco)-polypeptide to be 9,881. The $M_{\mathrm{r}}$ of the polypeptide portion calculated from its amino acid sequence (Fig. 3) is 8,588. This yields a mass difference of 1,293 . This mass difference would be sufficient to accommodate the common oligosaccharide core structure of glycoproteins, GlcNac $\mathrm{Man}_{3}$, but is not of sufficient magnitude, 1,373, to be equivalent to the oligosaccharide attached to bean PGIP (32). The total mass difference between that of the predicted polypeptide chain of CmPGIP and its total mass by MALDI-TOF MS is 4,085 and is likely to represent attached carbohydrate. If the apparent nominal mass of the oligosaccharide attached at Asn 231 is subtracted from the total mass of 4,085 , the difference is 2,792 . This mass of putative carbohydrate could accommodate two oligosaccharides of size similar to those attached to bean PGIP and suggests that Asn 83 and Asn 268 of CmPGIP may be glycosylated.

Like other PGIPs, CmPGIP appears to bind specifically to endo-PGs. CmPGIP inhibits PGs from two natural fungal patho-

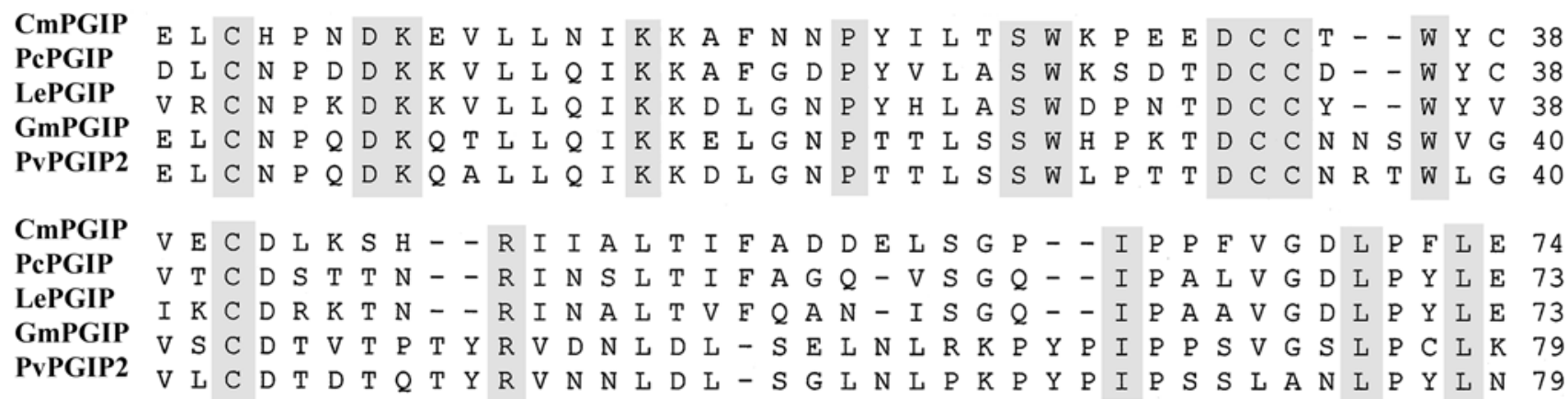

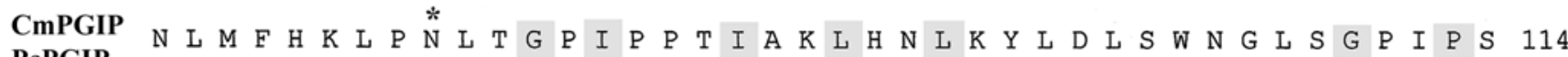

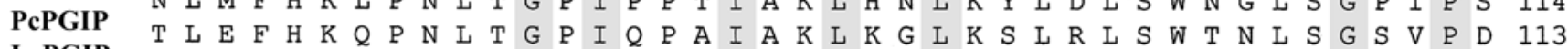

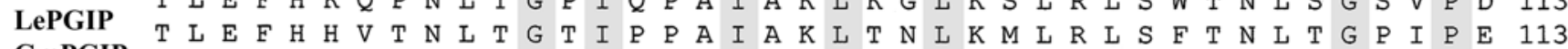

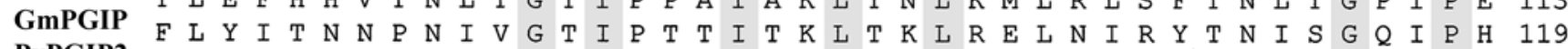

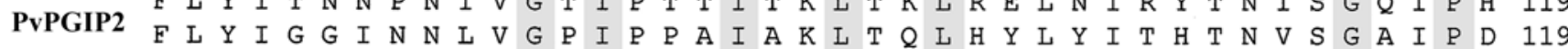

CmPGIP F L G S L S N L D I L D L S F N R F T G S I P S S L A N L R R L G T L H L D R N 154

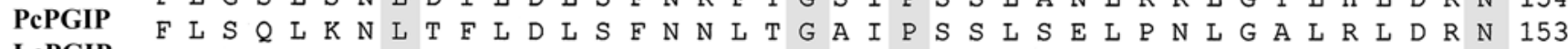

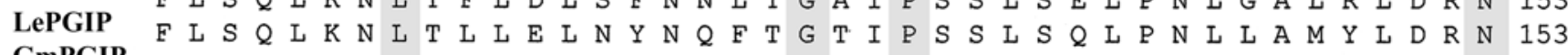

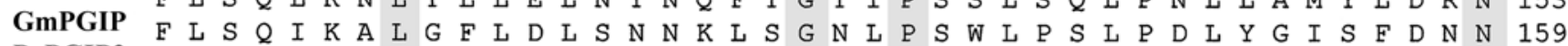

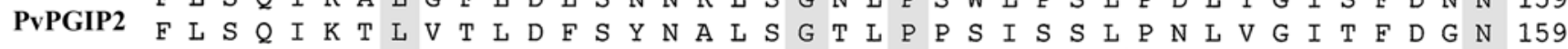

CmPGIP K L T G P I P D S F G N F K G - K V P Y L Y L S H N Q L S G K I P T S M G K V D 193 PcPGIP K L T G H $I$ P $\begin{array}{lllllllllllllllllllllllllllllllllllllllllll}\text { LePGIP } & K & \text { L } & T & G & T & I & P & E & S & F & G & R & F & K & G & P & N & I & P & D & L & Y & L & S & H & N & S & L & T & G & H & V & P & A & S & L & G & D & L & N & 193\end{array}$

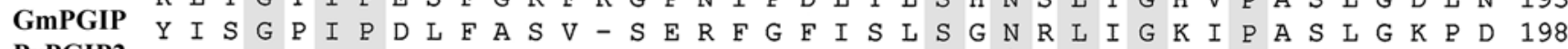

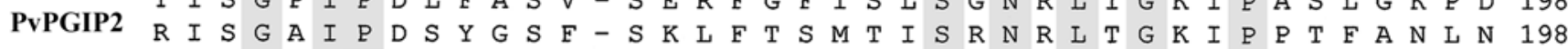

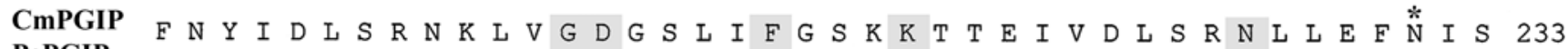

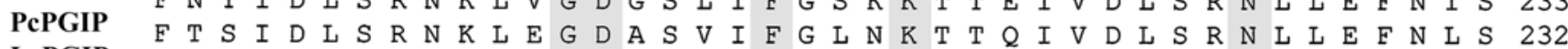

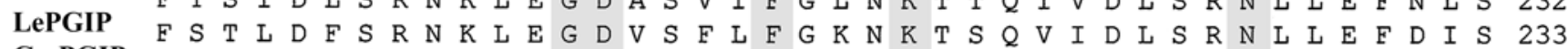
GmPGIP M K I V D L S R N M L E G D A S V L F G S E K H T E R I Y L A $N$ N

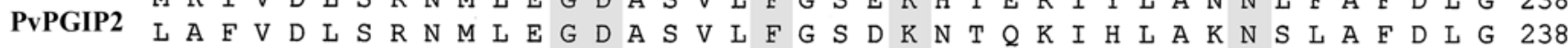

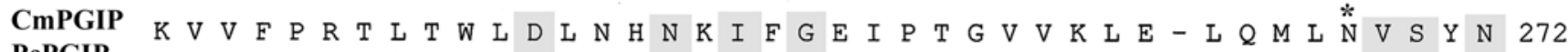

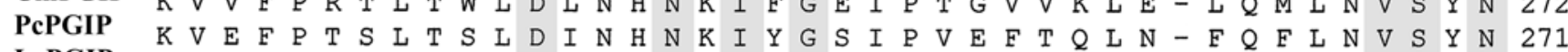

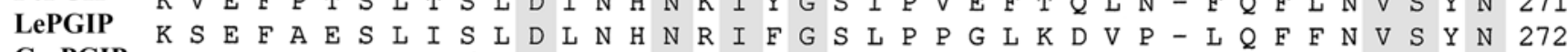

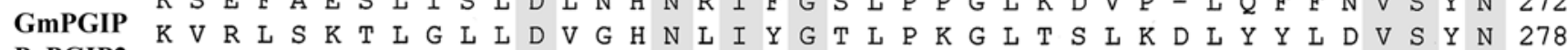

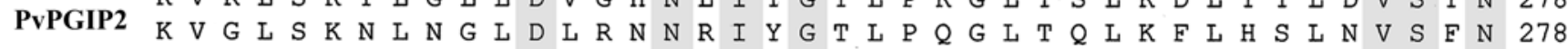

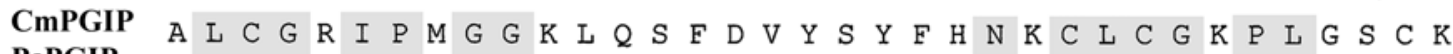

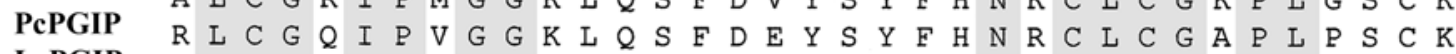

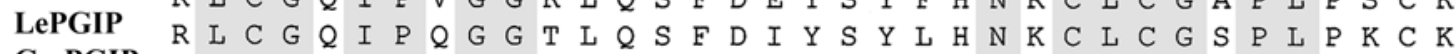

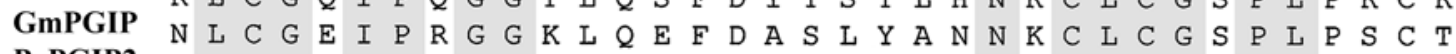

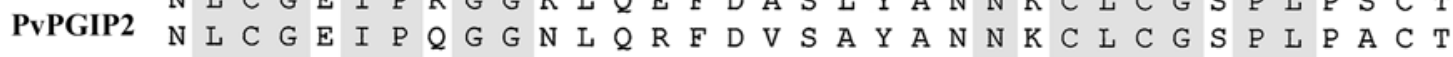

Fig. 3. Comparison of cantaloupe polygalacturonase-inhibiting proteins (CmPGIP) amino acid sequence with other PGIP sequences. The predicted amino acid sequences are given in the single letter code. Sequences aligned are CmPGIP, Cucumis melo; P-PGIP, Pyrus communis (40); LePGIP, Lycopersicon esculentum (39); GmPGIP, Glycine max (29); and PvPGIP2, Phaseolus vulgaris PGIP2 (28). The amino acid sequences were aligned using MegAlign 4.05 software (DNASTAR Inc., Madison, WI). Conserved regions are shaded. 
gens of cantaloupe as well as that of A. niger. Rhizopus sp., $D$. bryoniae, and $F$. verticillioides $\mathrm{PG}$ are inhibited very little or not at all by CmPGIP. D. bryoniae is a cantaloupe pathogen that is more likely to attack immature cantaloupe fruit (44) and thus its endo-PG might be anticipated to be unaffected by CmPGIP. Furthermore, it has been reported that $D$. bryoniae PG isozymes obtained from lesions on immature cantaloupe fruit are predominantly exo-PG (44), whereas $P$. cucurbitae (45) and F. solani (46) exhibit appreciable endo-PG activities. Also of interest is the fact that CmPGIP, like PGIPs from a number of other plants, does not inhibit PG from $F$. verticillioides (previously known as $F$. moniliforme) (summarized in 13). Leckie et al. (28) elegantly demonstrated with bean $P v$ PGIP2 and an $F$. verticillioides PG that position 219 (numbering of Figure 3) is intimately involved in its recognition and binding to $\mathrm{PG}$. Pear, tomato, and grape PGIPs have been shown to be ineffective against $F$. verticillioides PG (summarized in literature citation 13). The amino acid sequences of CmPGIP and the aforementioned PGIPs are highly variable over the linear sequence 10 residues either side of position 219 and exhibit little sequence homology with bean $P v$ PGIP2. These observations suggest that this linear region of PGIP is prominent in the PG-binding domain of PGIP.

Northern blot analysis on total RNA isolated from immature cantaloupe fruit tissue revealed one mRNA of $1.25 \mathrm{~kb}$. Interestingly, mature cantaloupe produced no detectable levels of pgip message, yet the mature fruit has measurable PGIP activity, albeit to a lesser extent than the immature fruit. This suggests one of three possibilities. First, the sensitivity of our northern blots was not high enough to detect the small amount of pgip message produced in mature cantaloupe fruit. Second, the protein found in mature fruit is a result of mRNA produced early on in the fruit maturation process. Third, the PGIP activity detected in the mature fruit is from a different gene product than we screened for by northern blots. Since immature fruit had a significant amount of

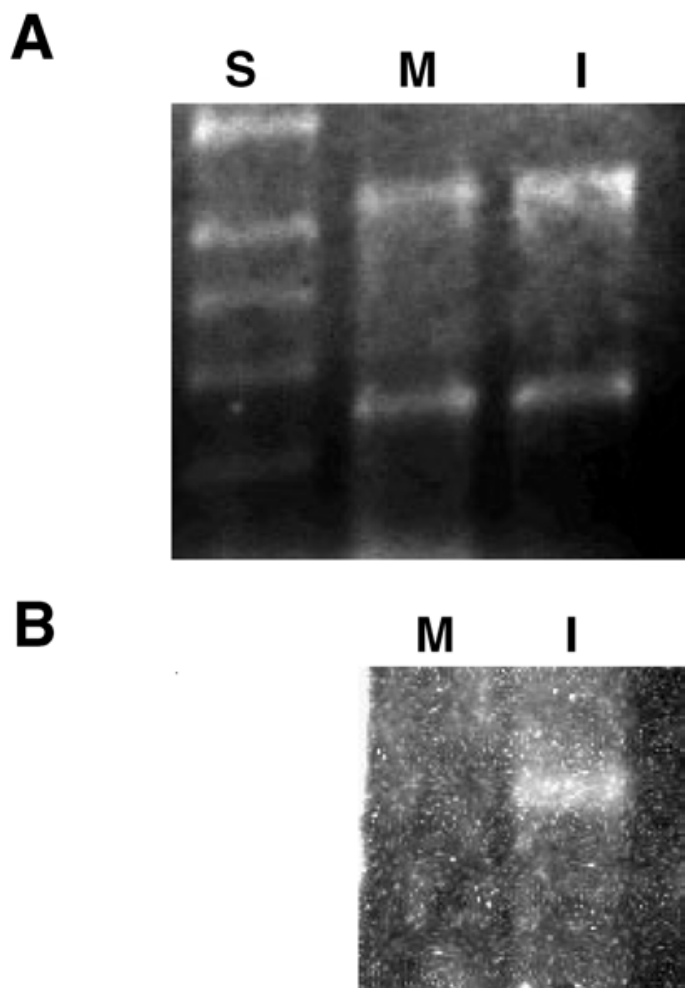

Fig. 4. Northern blot analysis of cantaloupe pgip. A, Denaturing RNA gel of $2 \mu \mathrm{g}$ Millennium mRNA size standard (S) for comparison to $15 \mu \mathrm{g}$ of total RNA from mature (M) and immature (I) cantaloupe fruit. B, Northern blot of cantaloupe polygalacturonase-inhibiting proteins (CmPGIP) message. This figure is representative of three northern blot experiments. pgip message and contained immature seed tissue, and the mature fruit sample did not contain seed tissue or detectable levels of mRNA, it is not inconceivable that the seed tissue produces high levels of pgip message. We plan to test this further.

In light of the fact that pgip gene families have clearly been shown to exist (13), as well as have expression of two or more of their gene products $(1,14)$, we feel it necessary to offer a caveat to our interpretation of the results we report on CmPGIP. Amino acid substitutions of only 1 to 3 positions out of 332 have been shown to change the functional properties of bean PGIP without changing its macromolecular physical and chemical properties $(28,32)$. Thus, it may be that the PGIP protein that we have isolated and characterized is not the product of the pgip gene we have cloned. It may instead be the product, or products, from one or more different members of the Cmpgip gene family.

\section{ACKNOWLEDGMENTS}

We thank R. Houser and A. Dillard for providing valuable technical support; S. Hartson and members of the Recombinant DNA/Protein Resource Facility at Oklahoma State University for their expertise and instrumentation for protein sequencing, rDNA sequencing, and MALDI-TOF MS; O. Spivey and members of the Analytical Ultracentrifuge Facility at Oklahoma State University for the use of the instrumentation and their help in data reduction; and J. Soulages of Oklahoma State University for use of the circular dichroism instrument and his aid in data reduction.

\section{LITERATURE CITED}

1. Abu-Goukh, A. A., Greve, L. C., and Labavitch, J. M. 1983. Purification and partial characterization of 'Bartlett' pear fruit polygalacturonase inhibitors. Physiol. Plant Pathol. 23:111-122.

2. Adler, A., Greenfield, N. J., and Fasman, G. D. 1973. Circular dichroism and optical rotatory dispersion of proteins and polypeptides. Methods Enzymol. 27:675-735.

3. Albersheim, P., and Anderson, A. J. 1971. Proteins from plant cell walls inhibit polygalacturonases secreted by plant pathogens. Proc. Natl. Acad. Sci. USA 68:1815-1819.

4. Ames, G. F.-L., and Nikaido, K. 1976. Two-dimensional gel electrophoresis of membrane proteins. Biochemistry 15:616-623.

5. Ausubel, F. M., Brent, R., Kingston, R. E., Moore, D. D., Seidman, J. G., Smith, J. A., and Struhl, K. (eds.) 1997. Current Protocols in Molecular Biology. John Wiley \& Sons, New York.

6. Beychok, S. 1967. Circular dichroism of poly- $\alpha$-amino acids and proteins. Pages 293-337 in: Poly- $\alpha$-Amino Acids: Protein Models for Conformational Studies. G. D. Fasman, ed. Marcel Dekker, New York.

7. Carpita, N. C., and Gibeaut, D. M. 1993. Structural models of primary cell walls in flowering plants: Consistency of molecular structure with the physical properties of wall during growth. Plant J. 3:1-30.

8. Cervone, F., DeLorenzo, G., Degra, L., Salvi, G., and Bergami, M. 1987. Purification and characterization of a polygalacturonase-inhibiting protein from Phaseolus vulgaris L. Plant Physiol. 85:631-637.

9. Chimwamurombe, P. M., Botha, A.-M., Wingfield, M. J., and Wingfield, B. D. 2001. Molecular relatedness of the polygalacturonase-inhibiting protein genes in Eucalyptus species. Theor. Appl. Genet. 102:645-650.

10. Chou, P. Y. 1989. Prediction of protein structural class from amino acid compositions. Pages 549-586 in: Prediction of Protein Structure and the Principles of Protein Conformation. G. D. Fasman, ed. Plenum Press, New York.

11. Cook, B. J., Clay, R. P., Bergmann, C. W., Albersheim, P., and Darville, A. G. 1999. Fungal polygalacturonases exhibit different substrate degradation patterns and differ in their susceptibilities to polygalacturonaseinhibiting proteins. Mol. Plant-Microbe Interact. 12:703-711.

12. DeLorenzo, G., Cervone, F., Bellincampi, D., Caprari, C., Clark, A. J., Desiderio, A., Devoto, A., Forrest, R., Leckie, F., Nuss, L., and Salvi, G. 1994. Polygalacturonase, PGIP and oligogalacturonides in cell-cell communication. Biochem. Soc. Trans. 22:394-397.

13. DeLorenzo, G., D'Ovidio, R., and Cervone, F. 2001. The role of polygalacturonase-inhibiting proteins (PGIPs) in defense against pathogenic fungi. Annu. Rev. Phytopathol. 39:313-335.

14. Desiderio, A., Aracri, B., Leckie, F., Mattei, B., Salvi, H., Tigelaar, H., Van Roekel, J. S. C., Baulcombe, D. C., Melchers, L. S., De Lorenzo, G., and Cervone, F. 1997. Polygalacturonase-inhibiting proteins (PGIPs) with different specificities are expressed in Phaseolus vulgaris. Mol. PlantMicrobe Interact. 10:852-860. 
15. Favaron, F., D’Ovidio, R., Porceddu, E., and Alghisi, P. 1994. Purification and molecular characterization of a soybean polygalacturonase-inhibiting protein. Planta 195:80-87.

16. Fish, W. W. 1975. Determination of the molecular weights of membrane proteins and polypeptides. Methods Membrane Biol. 4:189-276.

17. Fish, W. W. 2002. The isolation and characterization of cantaloupe fruit polygalacturonase-inhibiting protein. FASEB J. 16:150.1.

18. Garnier, J., and Robinson, B. 1989. The GOR method for predicting secondary structures in proteins. Pages 417-465 in: Prediction of Protein Structure and the Principles of Protein Conformation. G.D. Fasman, ed. Plenum Press, New York.

19. Glossman, H., and Neville, D. M., Jr. 1971. Glycoproteins of cell surfaces. A comparative study of three different cell surfaces of the rat. J. Biol. Chem. 246:6339-6346.

20. Gross, K. C. 1982. A rapid and sensitive spectrophotometric method for assaying polygalacturonase using 2-cyanoacetamide. HortScience 17: 933-934.

21. Habeeb, A. F. S. A. 1972. Reaction of protein sulfhydryl groups with Ellman's reagent. Methods Enzymol. 25:457-464.

22. Hahn, M. G., Bucheli, P., Cervone, F., Doares, S. H., O'Neill, R. A., Darvill, R. A., and Albersheim, P. 1989. Roles of cell wall constituents in plant-pathogen interactions. Pages 131-181 in: Plant-Microbe Interactions: Molecular and Genetic Perspectives, Vol. 3. T. Kosuge and E. W. Nester, eds. McGraw Hill, New York.

23. Jones, D. A., and Jones, J. D. G. 1997. The role of leucine-rich repeat proteins in plant defenses. Adv. Bot. Res. 24:89-167.

24. Jones, T. M., Anderson, A. J., and Albersheim, P. 1972. Host-pathogen interactions. IV. Studies on the polysaccharide-degrading enzymes secreted by Fusarium oxysporum f. sp. lycopersici. Plant Pathol. 2:153-156.

25. Karr, A. L., and Albersheim, P. 1970. Polysaccharide-degrading enzymes are unable to attack plant cell walls without prior action by a "wall-modifying" enzyme. Plant Physiol. 46:69-80.

26. Laemmli, U. K. 1970. Cleavage of structural proteins during the assembly of the head of bacteriophage T4. Nature 227:680-685.

27. Lafitte, C., Bartiie, J. P., Montillet, J. L., and Touze, A. 1984. Glycoprotein inhibitors of Colletotrichum lindemuthianum endopolygalacturonase in near isogenic lines of Phaseolus vulgaris resistant and susceptible to anthracnose. Physiol. Plant Pathol. 25:39-53.

28. Leckie, F., Mattei, B., Capodicasa, C., Hemmings, A., Nuss, L., Aracri, B., De Lorenzo, G., and Cervone, F. 1999. The specificity of polygalacturonase-inhibiting protein (PGIP): A single amino acid substitution in the solvent-exposed $\beta$-strand/ $\beta$-turn region of the leucine-rich repeats (LRRs) confers a new recognition capability. EMBO J. 18:2352-2363.

29. Mahalingam, R., Wang, G. J., and Knap, H. T. 1999. Polygalacturonase and polygalacturonase inhibitor protein: Gene isolation and transcription in Glycine max-Heterodera glycines interactions. Mol. Plant-Microbe Interact. 12:490-498.

30. Mankarios, A. T., and Friend, J. 1980. Polysaccharide-degrading enzymes of Botrytis allii and Sclerotium cepivorium. Enzyme production in culture and the effect of the enzymes on isolated onion cell walls. Physiol. Plant Pathol. 17:93-104.

31. Mann, K. G., and Fish, W. W. 1972. Protein polypeptide chain molecular weights by gel chromatography in guanidinium chloride. Methods Enzymol. 26:28-42.

32. Mattei, B., Bernalda, M. S., Federici, L., Roepstorff, P., Cervone, F., and Boffi, A. 2001. Secondary structure and post-translational modifications of the leucine-rich repeat protein PGIP (polygalacturonase-inhibiting protein) from Phaseolus vulgaris. Biochemistry 40:569-576.

33. Mirgorodskaya, K., Krogh, T. N., and Roepstorff, P. 2000. Methods in Molecular Biology. Proteins and Peptide Analysis-New Mass Spectrometric Applications. J. R. Chapman, ed. Humana Press, Totowa, NJ.

34. Pace, C. N., Vajdos, F., Fee, L., Grimsley, G., and Gray, T. 1995. How to measure and predict the molar absorption coefficient of a protein. Protein Sci. 4:2411-2423.

35. Pikal-Cleland, K. A., Rodrigurz-Hornedo, N., Amidon, G. L., and Carpenter, J. F. 2000. Protein denaturation during freezing and thawing in phosphate buffer systems: Monomeric and tetrameric $\beta$-galactosidase. Arch. Biochem. Biophys. 384:398-406.

36. Scopes, R. K. 1974. Measurement of protein by spectrophotometry at 205 nm. Anal. Biochem. 59:277-282.

37. Skare, N. H., Paus, F., and Raa, J. 1975. Production of pectinase and cellulase by Cladosporium cucumerinum with dissolved carbohydrates and isolated cell walls of cucumber as carbon sources. Physiol. Plant 33:229-233.

38. Sreerama, N., and Woody, R. W. 1994. Protein secondary structure from circular dichroism spectroscopy-combining variable selection principle and cluster-analysis with neural-network, ridge regression and selfconsistent methods. J. Mol. Biol. 242:497-507.

39. Stotz, H. K., Contos, J. J. A., Powell, A. L. T., Bennett, A. B., and Labavitch, J. M. 1994. Structure and expression of an inhibitor of fungal polygalacturonases from tomato. Plant Mol. Biol. 25:607-617.

40. Stotz, H. U., Powell, A. L. T., Damon, S. E., Greve, L. C., Bennett, A. B., and Labavitch, J. M. 1993. Molecular characterization of a polygalacturonase inhibitor from Pyrus communis L. cv. Bartlett. Plant Physiol. 102:133-138.

41. Tanford, C. 1968. Protein denaturation. Pages 121-282 in: Advances in Protein Chemistry, Vol. 23. C. B. Anfinsen, Jr., M. L. Anson, J. T. Edsall, and F. M. Richards, eds. Academic Press, New York.

42. Yao, C. L., Conway, W. S., Ren, R. H., Smith, D., Ross, G. S., and Sams, C. E. 1999. Gene encoding polygalacturonase inhibitor in apple fruit is developmentally regulated and activated by wounding and fungal infection. Plant Mol. Biol. 39:1231-1241.

43. Yao, C. L., Conway, W. S., and Sams, C. E. 1995. Purification and characterization of a polygalacturonase-inhibiting protein from apple fruit. Phytopathology 85:1373-1377.

44. Zhang, J. X., and Bruton, B. D. 1999. Relationship of developmental stage of cantaloupe fruit to black rot susceptibility and enzyme production by Didymella bryoniae. Plant Dis. 83:1025-1032.

45. Zhang, J. X., Bruton, B. D., and Biles, C. L. 1997. Polygalacturonase isozymes produced by Phomopsis cucurbitae in relation to postharvest decay of cantaloupe fruit. Phytopathology 87:1020-1024.

46. Zhang, J. X., Bruton, B. D., and Biles, C. L. 1999. Fusarium solani endopolygalacturonase from decayed muskmelon fruit: Purification and characterization. Physiol. Mol. Plant Pathol. 54:171-186. 